\title{
Sixteen years' experience of counselling, diagnosis, and prenatal detection in one Genetic Centre: progress, results, and problems
}

\author{
P. E. POLANi, E. AlbERMAN, B. J. AlEXANDER, P. F. BENSON,
} A. C. BERRY, S. BLUNT, M. G. DAKER, A. H. FENSOM, D. M. GARRETI V. M. MCGUIRE, J. A. FRASER ROBERTS, M. J. SELLER, AND J. D. SINGER

From the Paediatric Research Unit, The Prince Philip Research Laboratories, Guy's Hospital Medical School, London SEI 9RT

SUMmaRY The work of one Genetic Centre over 16 years, covering about 14000 kinships, ds described. The numbers registered in a year increased from an average of 477 in the early 1960 s to 1612 in 1976/1977. The increase is largely, but not entirely, attributable to the advent of prenatel diagnosis, and an account is given of our experience with this. In 1916 patients who had a successf 1 amniocentesis, results indicative of fetal abnormality were found in $4.3 \%$ and a balanced translocat tion was found in an additional $0.9 \%$. Results indicative of fetal abnormality were found in $3.5 \%$ of mothers referred because of a maternal age of 40 or more, $3.9 \%$ referred because of a high risk of neural tube defect, and $19 \cdot 3 \%$ referred because of a high risk of an inborn error of metabolisin. A number of cases with difficult diagnostic problems are described.

The Paediatric Research Unit was set up with the aim of preventing congenital disorders, primarily by pursuing research into causes and by the subsequent application of the research findings through counselling and diagnostic services.

Since the Unit's inception in 1960 about 14000 kinships have been registered with it, either because one or more members had been referred for diagnosis or advice, or following the discovery of abnormalities in the course of specific population surveys. The latter group was always offered, and often accepted, genetic counselling. From 1971 the chromosome diagnostic work was partly supported by the Department of Health and Social Security on a service basis, and from 1973 the support was extended to amniotic cytology. The South-East Thames Regional Genetics Centre was established in the Unit in 1976 and the Supraregional Laboratory for Tissue Enzymes in 1973.

The following is an account of the work of this Unit, and is offered in the hope that the experiences described may be helpful to others who are planning Genetic Centres.
The major causes for referral by kinship

Table 1 gives a broad classification of the causes för referral between 1960 and 1977, and shows how the number of families registered per year has increased since the inception of the Unit. These data ase related to workload, but are not identical to $\stackrel{q}{\text {, }}$ since many members of one kinship may be seen, Gr several visits paid by one family. In either case, the families are counted only once, so that the workload is substantially larger than the figures given. On the other hand, not all of those registered have had counselling appointments, since requests for chres mosome analysis may be confined to the analysis of a blood sample sent by post. From 1975 to 1979 approximately $50 \%$ of those registered were seen in the Unit. The proportion was greater in earlier years

Before the introduction of prenatal diagnosis or of carrier detection, genetic advice was limited probability counselling; that is, explaining families at risk the chances of producing further affected children. The major change which has occurred has been the advent of prenatal diagnosis, but the background work, other than during pres. nancy, of cytogenetic diagnosis, biochemistry, and genetic counselling of families has also continued $\$$ 166 
Table 1 New kinship registrations by 5-year periods by reason for genetic counselling or diagnosis

\begin{tabular}{|c|c|c|c|c|c|c|c|c|c|c|c|}
\hline \multirow{3}{*}{$\begin{array}{l}\text { Referral } \\
\text { period }\end{array}$} & \multirow[t]{3}{*}{ All } & \multicolumn{7}{|c|}{ Diagnosis or counselling without prenatal diagnosis } & \multirow{3}{*}{$\begin{array}{l}\text { Prenatal } \\
\text { diagnosis }\end{array}$} & \multirow{3}{*}{$\begin{array}{l}\text { Population } \\
\text { surveys } \\
\text { (chromosomes } \\
\text { only) }\end{array}$} & \multirow{3}{*}{$\begin{array}{l}\text { Average } \\
\text { registrations } \\
\text { per year } \\
\text { (excluding } \\
\text { population } \\
\text { surveys in } \\
\text { brackets) }\end{array}$} \\
\hline & & \multicolumn{2}{|c|}{ Chromosomes } & \multicolumn{2}{|c|}{ Single genes } & \multirow{2}{*}{$\begin{array}{l}\text { Multi- } \\
\text { factorial }\end{array}$} & \multirow{2}{*}{$\begin{array}{l}\text { Malig- } \\
\text { nancy }\end{array}$} & \multirow{2}{*}{$\begin{array}{l}\text { Miscel- } \\
\text { laneous }\end{array}$} & & & \\
\hline & & Down's & Other & Sex & Autosomes & & & & & & \\
\hline $\begin{array}{l}1.10 .60- \\
30.6 .65\end{array}$ & 2383 & 469 & 561 & 11 & 115 & 164 & 22 & 396 & - & 645 & 477 (348) \\
\hline $\begin{array}{c}1.7 .65- \\
30.6 .70\end{array}$ & 3844 & 559 & 1025 & 14 & 280 & 339 & 27 & 390 & 4 & 1206 & $769(528)$ \\
\hline $\begin{array}{c}1.7 .70- \\
30.6 .75\end{array}$ & 4438 & 374 & 916 & 47 & 350 & 411 & 105 & 334 & 1247 & 654 & $888(757)$ \\
\hline $\begin{array}{l}1.7 .75- \\
30.6 .77 \\
(2 \text { y only) }\end{array}$ & 3330 & 172 & 607 & 57 & 270 & 233 & 130 & 229 & 1526 & 106 & 1665 (1612) \\
\hline
\end{tabular}

increase. It should be noted, however, that in a substantial proportion of families at risk for genetic disease, probability counselling still remains the only option.

Throughout this time about one quarter of the kinships registered had been derived from research chromosome surveys of selected populations, but this proportion has decreased over the years. The fall in the referrals for the diagnosis of Down's syndrome reflects the expansion of laboratory facilities in other hospitals in the region. In contrast, referrals for conditions caused by single genes have doubled, for advice on multifactorial conditions trebled, and for karyotyping in patients with malignancy, for example, leukaemia, have increased even more.

Several of the techniques required for diagnosis of metabolic disorders in cultured fibroblasts or amniotic fluid cells were developed in the Unit (Fensom et al., 1974, 1976, 1977, 1978; Stirling et al., 1978), or exploited for the first time (Ramsay et al., 1974; F. G. Giannelli, 1976, personal communication), so that referrals for these conditions have also increased.

\section{Prenatal diagnosis}

DEVELOPMENT AND POLICIES IN THE UNIT From the autumn of 1969, the Unit began to offer a prenatal diagnosis service for chromosome disorders and soon followed this with the offer of prenatal diagnosis of inborn errors of metabolism. From 1972 onwards, a diagnostic service for neural tube defects (NTD) was offered, with the measurement of alphafetoprotein (AFP) in amniotic fluid. Some of the findings have already been published as individual case reports including Seller (1975), Campbell et al. (1976), Blunt et al. (1977), and 546 amniocentesis patients (and their controls) are included in the Medical Research Council (MRC) Working Party on Amniocentesis Report (1978).
The policy regarding the tests done on a specimen of amniotic fluid changed somewhat over the years. Before 1972 the only 'service' investigations were those done for chromosome analysis. Estimations of AFP levels in all fluids received were carried out immediately after the first published indication of its importance for the diagnosis of NTD (Brock and Sutcliffe, 1972). Since AFP studies were being done in the Unit (Adinolfi et al., 1975) at that time, this application was a natural extension of our work. For a few months all fluid taken primarily for this test also had a chromosome analysis performed on it. This soon overstretched the cytogenetic resources of the Unit because of the concurrent increase in demand for karyotyping alone, and from early 1973 amniotic fluid cells from pregnancies at risk for NTD were only cultured where the mother's age, or history, put her at risk of a fetal chromosomal anomaly. As AFP estimations on amniotic fluid are much simpler and cheaper, these have always been done routinely on every amniotic fluid received, regardless of the indication for the test. The amniotic fluid samples of all fetuses investigated for biochemical errors were studied chromosomally. The Fig. gives some indication of the increase in the numbers of amniotic fluids examined.

From the summer of 1977, the Unit has been able to carry out prenatal diagnosis for all 40 metabolic diseases which can be detected reliably in the United Kingdom. Occasionally, samples are divided between ourselves and another laboratory, particularly when techniques are, or were, still experimental, for example, for specific biochemical tests. For simplicity all split samples have been included in the data presented.

\section{MOTHERS REFERRED FOR AMNIOCENTESIS}

Referrals for prenatal diagnosis come from obstetricians, family doctors, and paediatricians, both from within and without the Regional Health Authority in which the Unit is situated. By the end of December 


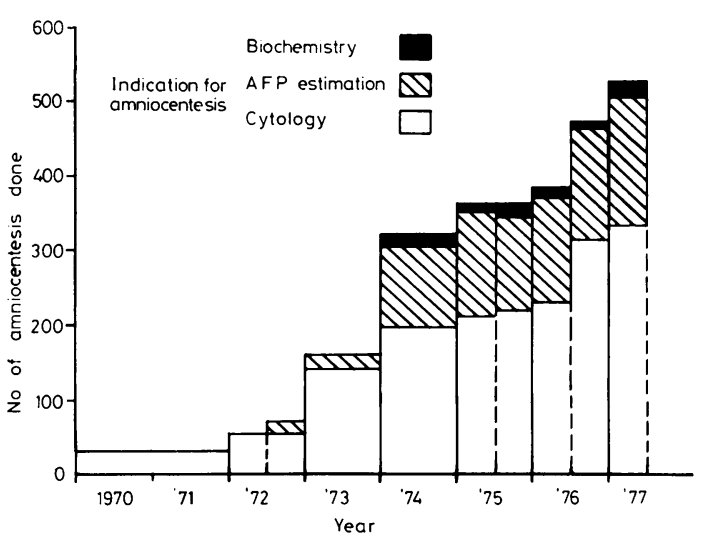

Fig. Indications for amniocentesis by year.

1976, 2605 mothers had been referred for this reason, but only $2068(79.4 \%)$ of these later came to amniocentesis. Between 1 January 1977 and the end of 1977 we had a further 1144 referrals in early pregnancy, of which $884(77 \cdot 3 \%)$ have had amniocentesis. The hospitals where amniocentesis was done varied with time, but for the sample described below $34 \%$ were carried out in Guy's. In the remainder, the fluids were sent to the Unit for analysis, usually by rail or car, rarely by post.

The reasons for which amniocentesis was not carried out were investigated in a sub-sample of 1277 referrals between the beginning of July 1975 to the end of December 1976. In 13 of these, it appears that amniocentesis was done elsewhere, but we have no record of the results. Of the remaining 1264 , amniocentesis was not attempted in $237(18.7 \%)$, a similar proportion to that in all referrals. The reasons were as follows: in $6.7 \%$ there was no clinical indication for amniocentesis; $6 \cdot 5 \%$ refused after counselling, often because they were at relatively low risk of producing an affected child, so that this risk approached that of the amniocentesis itself; $4.8 \%$ aborted spontaneously before the amniocentesis was arranged; and in $0.7 \%$ the obstetrician advised against the operation.

\section{INDICATIONS FOR AMNIOCENTESIS AND ASSOCIATED PROCEDURES}

The Fig. shows how the proportions of amniocenteses carried out for cytology, AFP, and biochemistry other than AFP have changed over the years. The rapid rise in the proportion done for AFP estimations was associated with the dissemination of information on its value in identifying affected pregnancies.

A more detailed breakdown by indication is shown in Table 2 and 3. As can be seen, some women had multiple indications. Of all indications, $38 \%$ wege for chromosome analysis because of maternal age and $35 \%$ for AFP because of NTD. Eighty-three $(4 \%)$ amniocenteses were carried out for inbo errors of metabolism; in 32 of these, cells were bo cultured and tested in the Unit (Table 3). Before prenatal diagnosis for metabolic disorders can $\overline{5}$ undertaken, it is important to confirm the specife enzyme defect in the propositus if possible, or in the carrier parents (or mother in X-linked disorders). This is a considerable proportion of the biochemica workload and has increased considerably each year since 1973 (Table 4). Of the total of 724 enzyne assays performed, 314 were on cultured fibroblast产, involving a heavy laboratory workload. Moreovef, since it is essential to do control assays, cells from one affected and two normal subjects are cultured and assayed at the same time as the test cells, so th four times as many cell cultures, or about 1250 , have actually been assayed biochemically.

SUCCESS RATES OF AMNIOTIC PUNCTURE ANI ANALYSIS OF FLUID

The results reported here are those from mothe $\overrightarrow{0}$ presenting between 1.9.69 to 31.12.76. Inevitablog we do not yet have complete outcome data on pregnancies presenting in 1977.

Of the 2068 mothers who came to amniocentesis 1814 had one tap only (Table 5), and the fluid was obtained and successfully analysed in $1694(93.4 \%$ The remaining 120 , in whom no laboratory resuit was obtained, are described below. Of the 258 gravidae who had two or more taps, fluid was obtained and successfully analysed in $222(87.4 \%$ Thus, the amniocentesis and laboratory failure rates are nearly double those of the mothers requi ing only one tap $(P<0 \cdot 01)$.

In slightly over half of the 152 (120 one tap, two or more) in whom no result was ever obtained, the failure was the result of a blood-stained fluid of a dry tap. In the remainder, there was a laboratory failure to establish diagnostically satisfactory amniotic cell cultures, both types of failure occurri more frequently in the earlier years.

In the 120 mothers who had only one attempt diagnosis (Table 5 and 6), no further action wăs taken in $16(13 \%)$ because fetal death had occurre There was evidence suggesting that in some of these the fetus had been dead or dying at the time of the first tap. In ten of these, the tap had succeeded bit amniotic cell culture failed. However, in two, a brow (but not bloody) supernatant fluid had been observed, in another three, the AFP level had been abnormally high, while in the sixth, the AFP level was so lo that fetal death and resorption had been suspecte 8 Of the remaining six mothers without results who hae 
a fetal loss and no second amniocentesis, four had a brown vaginal loss was present. The remaining two dry tap, and in one of these the sonicaid fetal heart aborted after a blood-stained tap. The other 104 monitor did not detect any heart sounds and a outcomes are described in Table 6.

Table 2 Individual indications for amniocentesis and information found at amniocentesis from referrals between 1.9.69-31.12.76

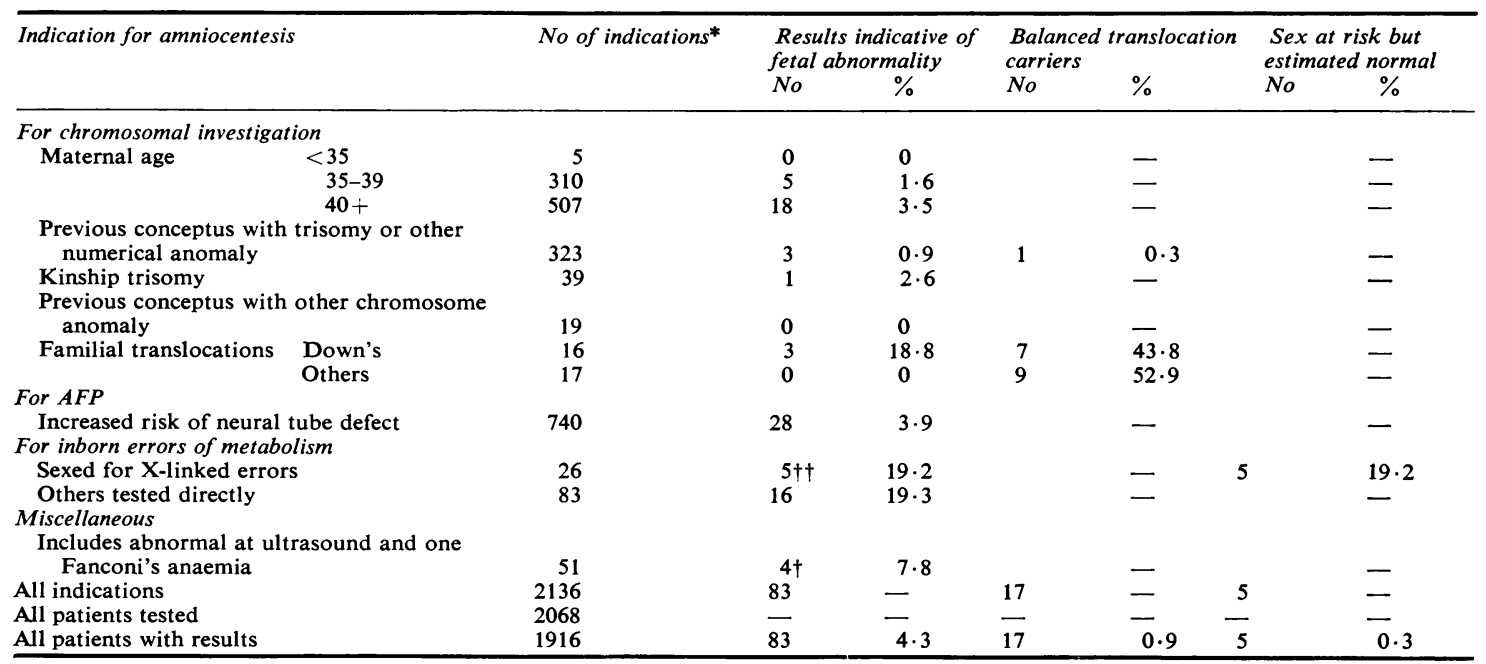

*61 cases entered both in chromosomal indication and previous neural tube defect; 7 cases entered twice in 'miscellaneous' because 2 indications; †all high AFP; ††estimated to be abnormal, ie, half of sex at risk.

Table 3 Prenatal diagnosis of metabolic disease

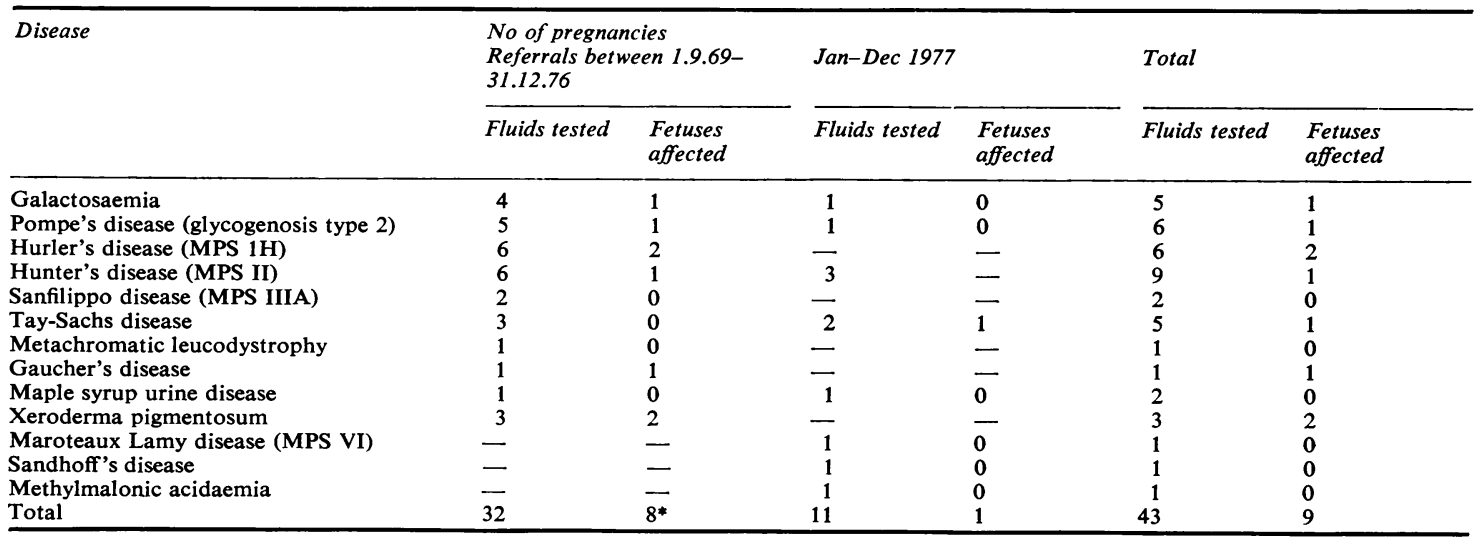

*These are included in Table 2 and 6.

Table 4 Number of assays performed up to 31.12.77

\begin{tabular}{lllccc}
\hline $\begin{array}{l}\text { Year } \\
\text { ending } \\
\text { 31 December }\end{array}$ & $\begin{array}{l}\text { Homo- } \\
\text { zygotes or } \\
\text { hemizygotes }\end{array}$ & $\begin{array}{l}\text { Hetero- } \\
\text { zygotes }\end{array}$ & Prenatal & $\begin{array}{c}\text { Post } \\
\text { mortem }\end{array}$ & Total \\
\hline 1973 & 8 & 26 & 3 & 0 & 37 \\
1974 & 57 & 19 & 10 & 4 & 90 \\
1975 & 131 & 21 & 8 & 4 & 164 \\
1976 & 150 & 28 & 11 & 3 & 192 \\
1977 & 183 & 46 & 11 & 1 & 241 \\
Total & 529 & 140 & 43 & 12 & 724 \\
\hline
\end{tabular}

Table 5 Amniotic punctures and results from referrals between 1.9.69-31.12.76

\begin{tabular}{|c|c|c|c|}
\hline & $\begin{array}{l}\text { No of } \\
\text { pregnancies }\end{array}$ & Results from & $\begin{array}{l}\text { No results } \\
\text { from }\end{array}$ \\
\hline $\begin{array}{l}\text { Single tap } \\
\text { Two taps } \\
\text { Three taps } \\
\text { Four taps } \\
\text { Total }\end{array}$ & $\left.\begin{array}{r}1814 \\
222 \\
29 \\
3\end{array}\right\} 254$ & $\left.\begin{array}{r}1694 \\
193 \\
26 \\
3\end{array}\right\} 222$ & $\begin{array}{r}120(6.6 \%) \\
29(13.0 \%) \\
3(10.3 \%) \\
-\quad \\
152(7.4 \%)\end{array}$ \\
\hline
\end{tabular}


Table 6 Outcome by result or no result of amniocentesis from referrals between 1.9.69-31.12.76

\begin{tabular}{|c|c|c|c|c|c|c|c|c|c|c|}
\hline \multirow[t]{2}{*}{ Outcome } & \multirow{2}{*}{\multicolumn{2}{|c|}{$\begin{array}{l}\text { Test result } \\
\text { known (\%) }\end{array}$}} & \multicolumn{4}{|c|}{ Test result not known } & \multirow{2}{*}{$\begin{array}{l}\text { All not } \\
\text { known } \\
\text { (Subtotal) }\end{array}$} & \multirow[b]{2}{*}{$(\%)$} & \multirow[t]{2}{*}{ Total } & \\
\hline & & & $\begin{array}{l}\text { One } \\
\text { tap }\end{array}$ & $(\%)$ & $\begin{array}{l}2 \text { or } \\
\text { more }\end{array}$ & $(\%)$ & & & & \\
\hline $\begin{array}{l}\text { Terminated for medical indication } \\
\text { Terminated on other grounds } \\
\text { Fetal or neonatal loss } \\
\text { Survivor } \\
\text { Outcome not known } \\
\text { All }\end{array}$ & $\begin{array}{r}82 \\
6 \\
81 \\
1653 \\
94 \\
1916\end{array}$ & $\begin{array}{r}4 \cdot 3 \\
0 \cdot 3 \\
4 \cdot 2 \\
86 \cdot 3 \\
4 \cdot 9 \\
100\end{array}$ & $\begin{array}{c}1^{*} \\
2 \\
18 \dagger \\
84 \\
15 \\
120\end{array}$ & $\begin{array}{r}0 \cdot 8 \\
1 \cdot 7 \\
15 \cdot 0 \\
70 \cdot 0 \\
12 \cdot 5 \\
100\end{array}$ & $\begin{array}{r}0 \\
0 \\
5 \\
24 \\
3 \\
32\end{array}$ & $\begin{array}{c}0 \\
0 \\
15 \cdot 6 \\
75 \cdot 0 \\
9 \cdot 4 \\
100\end{array}$ & $\begin{array}{r}1 \\
2 \\
23 \\
108 \\
18 \\
152\end{array}$ & $\begin{array}{r}0 \cdot 7 \\
1 \cdot 3 \\
15 \cdot 1 \\
71 \cdot 1 \\
11 \cdot 8 \\
100\end{array}$ & $\begin{array}{r}83 \\
8 \\
104 \\
1761 \\
112 \\
2068\end{array}$ & 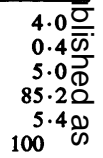 \\
\hline
\end{tabular}

*Split specimen with abnormal result obtained elsewhere;

$\dagger 16$ aborted or diagnosed as IUD before repeat could be organised (see text) and 2 neonatal deaths.

\section{RESULTS BY INDICATION}

Table 2 shows the results of the successful amniocenteses according to the indication for the test. Overall, $4 \cdot 3 \%$ of all successful amniocenteses produced evidence of fetal abnormality, and an additional $0.9 \%$ detected a fetus with a balanced structural chromosome anomaly.

As expected, the highest yield of cytogenetic anomalies was in those pregnancies with familial translocations, of which balanced carriers were found in nearly half the karyotyped fetuses and unbalanced abnormalities in $9.4 \%$. The yield of chromosomal abnormalities in mothers referred for maternal age was much lower, $2 \cdot 8 \%$ in all mothers aged 35 or more, and $3.5 \%$ in those aged 40 or more. A similar proportion of abnormality, $3.9 \%$, was obtained in mothers tested because of a previous infant with NTD. Sixteen $(19.3 \%)$ of the 83 fetuses tested because of a family history of an inborn error of metabolism were affected.

From the biochemical tests carried out entirely in the Unit before 1977 (Table 3), of 26 pregnancies at high risk of an autosomal recessive disorder the fetus was judged to be heterozygous in $4(15 \%)$, but discrimination between carriers and normal homozygous amniotic cells is unsatisfactory for several of these conditions and is of academic importance only.

\section{ACTION TAKEN AS A CONSEQUENCE OF AMNIOCENTESIS RESULTS AND VALIDATION OF RESULTS}

There were 105 mothers in whom the result was either frankly abnormal, or showed a balanced chromosome anomaly, or showed the sex at high risk for a sex-linked abnormality. The position in regard to heterozygotes for recessive inborn errors has already been discussed. Of the pregnancies in which a result was obtained up to the end of 1976,83 $(4.3 \%)$ were terminated. These are described in detail below. If patients referred in 1977 are considered, a further 26 were found to have an abnormal result and were terminated, reflecting the increasing rate of referral.
Table 7 Chromosome anomalies found in amniotic cells from referrals 31.12.69-31.12.76

\begin{tabular}{|c|c|}
\hline Trisomy or other abnormality & $\begin{array}{l}\text { Primary trisomy } 21 \\
\text { Other }\end{array}$ \\
\hline \multirow[t]{2}{*}{ Balanced translocation } & $\begin{array}{l}\text { Centric fusion involving } \\
\text { no } 21 \\
\text { Other }\end{array}$ \\
\hline & Total \\
\hline
\end{tabular}

\section{Chromosome anomalies}

Table 7 shows the distribution of these. Of the pregnancies with unbalanced anomalies shown in the Table, 27 were terminated. In six instances the fetio was not available for study or tissue culture faile but in one of these the fetus had features of Down? syndrome. In 19, fetal karyotyping confirmed the amniotic fluid findings. In one case, the amniot fluid showed mosaicism, but no trisomic cells were found in fetal tissue. This is discussed later. Finally one of the 27 was terminated after an amniotic flugad diagnosis of trisomy 21 , and was unexpectedly fourd to be twins, one with trisomy 21 , the other with normal karyotype. This happened in 1973 when experience in ultrasound diagnosis was limited.

In the three pregnancies which were not terminis ted, the amniotic fluid had shown karyotype 47,XX范, $47, X X X$, and $46, X X / 47, X X+$ fragment, respec: tively (see below). In each, the parents elected to continue the pregnancy and the children were of normal appearance and behaviour on follow-up.

Of the 17 pregnancies in which the fetus was show to carry a balanced translocation, 15 continued term. The sixteenth aborted spontaneously some time after amniocentesis and the last was terminated at another centre because of maternal anxiety. The amniotic fluid findings were confirmed in the lattę․

Raised alphafetoprotein

Raised AFP levels were found in amniotic fluigh from 42 mothers. Of these, 7 subsequently aborteḑa 
macerated fetus, and in every case the fluid was a dark brown colour (Seller, 1977), suggesting that the high value was accounted for by intrauterine death (3 have been mentioned earlier). In 3, the raised AFP level was associated with severe fresh blood contamination of the fluid (Table 8). However, second samples obtained a week after the first were clear and had a normal AFP value, so the pregnancies were allowed to continue to term and normal infants were delivered. One continued to term because it was a twin pregnancy with one normal and one affected fetus (Campbell et al., 1976). A total of 31 pregnancies were terminated and in 28 the fetus showed an abnormality (27 NTD including 2 with Meckel's syndrome, one other with multiple anomalies including omphalocele). Of the remaining three, one fetus appeared normal but the placenta was grossly abnormal. In the second, the fetus and placenta were normal; two successive amniotic fluid samples had had raised AFP values, but both were severely blood-stained. At that time we did not recognise the significance of fetal blood contamination. The third was a fluid assayed to confirm the findings of a collaborating centre, and though we confirmed their high AFP value they reported finding a normal fetus on termination.

If we count all these cases, including patients of another centre, the unexplained false-positive rate would be 1 in just over 2000 fluids tested for AFP. On the other hand, as far as our own patients are concerned, the two with raised AFP but no fetal abnormality could be accounted for as described above.
Inborn errors and directly detected $X$-linked conditions

Of 16 affected fetuses detected by direct testing (Table 2), 8 tested in conjunction with other laboratories were terminated, but are not further considered here. Of the remaining 8,7 pregnancies were terminated and the diagnosis confirmed (Table 3), while the eighth (galactosaemia) proceeded to term and the diagnosis was confirmed by enzyme assay on cord blood. Where direct testing was not possible, all 10 pregnancies found to have a fetus of the high risk sex were terminated.

\section{OUTCOME OF PREGNANCY AFTER}

\section{AMNIOCENTESIS}

An important part of the prenatal diagnosis evaluation is to obtain reports on the outcome of all pregnancies. The outcome of the pregnancies that came to amniocentesis, distinguishing those in whom the result of the amniocentesis was and was not known, is given in Table 6. Information on outcome has been obtained on $95 \%$ of all pregnancies receiving amniocentesis up to the end of 1976.

Overall, at least $85.2 \%$ of all pregnancies ended with a live baby. In those in whom the test result was known, this figure was $86.3 \%$ and in whom outcome was known, $90 \%$. No case is known where a chromosomally abnormal fetus was diagnosed as normal, but in one case AFP was reported as normal in a patient who later aborted a fetus with a skincovered encephalocele. The Unit does not routinely have follow-up information on these children and cannot therefore report on their current health, but

Table 8 Problem results: referrals between 1.9.69-31.12.76

\begin{tabular}{|c|c|c|c|c|c|c|}
\hline \multirow[t]{2}{*}{ Patient no } & \multicolumn{2}{|l|}{ Finding } & \multirow[t]{2}{*}{ Action } & \multicolumn{3}{|l|}{ Fetus or infant } \\
\hline & First sample & Second sample & & $\begin{array}{l}\text { Macroscopic } \\
\text { appearance }\end{array}$ & Chromosomes & Phenotypic sex \\
\hline \multicolumn{7}{|c|}{ (a) Chromosomes } \\
\hline $7708^{*}$ & $46, X X / 47, X X,+G_{A}$ & $46, \mathrm{XX} / 47, \mathrm{XX},+? \mathrm{G}_{\mathrm{A}}$ & Terminated & $\begin{array}{l}\text { ? Abnormal } \\
\text { dermatoglyphs }\end{array}$ & $46, X X$ & $\mathbf{F}$ \\
\hline $8649^{*}$ & $46, \mathrm{XX} / 47, \mathrm{XX},+$ frag & No repeat & Continued & Normal & $46, X X$ & $\mathrm{~F}$ \\
\hline 8380 & $46, \mathrm{XY} / 46, \mathrm{XX}$ & No repeat & $\begin{array}{l}\text { Premature neonatal } \\
\text { death }\end{array}$ & Abnormal & - & $\mathbf{M}$ \\
\hline 10588 & $46, \mathrm{XY} / 46, \mathrm{XX}$ & No repeat & Continued & Normal & - & $\mathbf{M}$ \\
\hline $11114^{*}$ & $\begin{array}{l}46, X X / 47, X X,+9 / 47, \\
X X,++? r\end{array}$ & As first & Terminated & Abnormal & $46, X X / 47, X X,+9$ & $\mathrm{~F}$ \\
\hline 11801 & $92, \times \times X \times$ & No repeat & Continued & Normal & 一 & $\mathbf{F}$ \\
\hline 11909* & $46, \mathrm{XX} / 47, \mathrm{XX},+$ frag & No repeat & Terminated & Normal & $46, X X / 47, X X,+r$ & $\mathrm{~F}$ \\
\hline 11969 & $45, \mathrm{X}$ & $46, X X$ & Continued & Normal & - & $\mathbf{F}$ \\
\hline $12271^{*}$ & $\begin{array}{l}46, X Y / 46, X, \operatorname{dic}(Y) \\
(\mathrm{qlil}) / 46, X, \operatorname{del}(\mathrm{Y})(\mathrm{qll})\end{array}$ & As first & Terminated & Epididymal cyst & $\begin{array}{l}\text { 46,XY/46,X,dic } \\
\text { (Y)(qll)/46,X,del(Y)(qli) }\end{array}$ & $\mathbf{M}$ \\
\hline \multicolumn{7}{|c|}{$(1)(\mathrm{q} 11) / 40, \lambda, \mathrm{del}(\mathrm{I})(\mathrm{q} 11)$} \\
\hline $9217^{*}$ & Fluid & $\begin{array}{l}\text { Fluid bloody, AFP } \\
\text { raised }\end{array}$ & Terminated & Normal & 一 & $\mathbf{M}$ \\
\hline \multirow{3}{*}{$\begin{array}{l}11642 \\
\text { AV49/MJS } \\
11885\end{array}$} & bloody & & Continued & Normal & 一 & $\mathbf{F}$ \\
\hline & AFP raised & $\begin{array}{l}\text { Fluid clear, } \\
\text { AFP normal }\end{array}$ & Continued & Normal & - & $\mathbf{M}$ \\
\hline & & & Continued & Normal & - & $\mathbf{M}$ \\
\hline
\end{tabular}

*Entered as abnormal result in Table 2 . 
many of these are included in the MRC study on outcome of amniocentesis, in which postnatal information was specifically sought.

Some pregnancies with unknown outcome are from mothers resident abroad whom we have been unable to trace, while others resident in this country may still be traced. As one might expect, the highest proportion of unknown pregnancy outcomes $(11 \cdot 8 \%)$ were in those pregnancies where no result was obtained on amniocentesis. It has been shown (Table 6) that in these the risk of fetal or neonatal death was highest, over three times the risk in those in whom results were obtained. This group of unknown results also included the only live birth with a chromosomal abnormality, trisomy 18, missed because amniotic cell culture had failed. There were four (normal) cases in which the sex at birth was different from that reported at amniocentesis; twice it was reported as female where a male was delivered, and twice a male where a female was delivered. In three of these, chromosome analysis of the newborn gave a result in accordance with the phenotypic sex, while the fourth (a boy) has not been karyotyped as he was initially rejected. The former two errors could have been the result of maternal cell contamination, the latter must have been a labelling or laboratory error.

All pregnancies tested because of risk of biochemical disorders have been followed up by enzyme assays on the newborn, and all predictions up to the time of writing (September 1978) have proven accurate.

\section{PROBLEMS OF DIAGNOSIS}

Certain puzzling situations presented which are reported here in the hope that the experience may be of use to others. The majority are set out in Table 8 and it can be seen that mosaicism is the chief problem. The two fluids containing both normal male and female cells produced male offspring, so maternal contamination is the most likely explanation. Mosaicism with an abnormal cell line was found five times. In the first, at culture the proportion of trisomic cells was small ( 3 of 200), the pregnancy was terminated, but no trisomic cells were identified in the fetus. However, the dermatoglyphic findings were compatible with mosaicism (Polani and Polani, 1969). In the second pregnancy, $10 \%$ amniotic cells contained an extra fragment. The parents elected to continue the pregnancy and a normal girl was born who had a normal peripheral blood chromosome complement; a fibroblast culture was not sought. In two other mosaics (11114 and 11909) and in the mosaic with a $\mathbf{Y}$ dicentric, the proportions of abnormal cells were high, the pregnancies were terminated, and the amniotic findings confirmed in the fetuses, though in the fetal cells of 11909 䨌 became clear that the small 'fragment' was a ring chromosome of unidentified origin.

Tetraploidy is a recognised artefact of amniotie fluid culture (Kohn and Robinson, 1970), so the finding did not cause undue anxiety. Of more concern was the $45, \mathrm{X}$ result in a mother aged 40. This is a rare anomaly among survivors, though th commonest among conceptions, and is not associate with advancing maternal age. The cells had been difficult to maintain in culture, so that a cultural artefact was suspected, particularly as $45, \mathrm{X}$ cells are known to have a rapid cell cycle and might have outgrown the original cells from which they ha been derived. Amniocentesis was repeated and showed cells with a karyotype of $46, \mathrm{XX}$. The mothe was reassured and a normal girl delivered at tern Not included in Table 8 are four apparently balancef translocations (three reciprocal, one centric fusiog $13 / 14$ ) in the amniotic fluid cells. Of these, 3 were found in fluid taken from mothers who had had a previous Down's syndrome infant. In 3, examination of the parental karyotype showed one or other parent to carry the reciprocal translocation and $\mathscr{Q}$ good prognosis was given. These have been include $\$$ under 'familial translocation other than Down's One fetus was found to have a reciprocal translocas tion involving chromosomes $2 \mathrm{q}$ and $18 \mathrm{p}$ that mus have arisen de novo assuming paternity was as stated Though it appeared balanced, it was difficult to be altogether reassuring regarding the prognosis. As at excessive incidence of apparently balanced trans locations is found in mentally retarded populations, each de novo translocation must be regarded wit suspicion as its effect on the phenotype is unknowi The parents elected to continue the pregnancy an a normal boy was born. When seen at age $2 \frac{1}{2}$ years he was physically and developmentally normal and. his unusual karyotype was confirmed.

In contrast to chromosomal analysis, in whic there is agreement on the recognition of most abnormalities, the cut-off points distinguishing normal from abnormal levels of AFP are large statistical estimates and their significance can b determined by experience only. In the early yearo, there were little data on the normal AFPrange, and each laboratory tended to use as the cut-off points its own highest estimation in mothers later delivering normal baby. Moreover, AFP results may be difficuift to interpret, particularly when the fluid is contame nated with fetal blood. A Kleihauer test is now alway performed on blood-stained fluids to determine the source of the contaminating blood. Detailed ultre sound scanning (by Professor Stuart Campbe has provided helpful confirmation of an abnormo result in many cases. 
Overall, $15(0 \cdot 8 \%)$ mothers of the 1916 (Table 2) in whom results were obtained had to be recalled and a possibly ambiguous result discussed with them. This inevitably causes considerable distress. With the use of chromosome banding techniques it is possible that this problem will increase, while greater experience with AFP results in individual laboratories may lead to a diminishing proportion of doubtful findings.

\section{Discussion}

Although the major part of the data in this account relates to prenatal diagnosis, we must stress that the results reported here should not be construed to indicate the safety or otherwise of amniocentesis. Information on this can only be derived from ad hoc studies with appropriate controls, such as the one by the National Institute of Child Health and Human Development (1976) or that conducted by the MRC (1978).

\section{CHANGES IN REFERRALS OVER THE YEARS}

The wide spread of diagnoses for which patients have been referred (Table 1) reflect the technical advances that took place between 1960 and 1976, and their increasing numbers mirror the changes in attitudes of the public and doctors to genetic counselling and its attendant diagnostic procedures. During these 16 years, in keeping with changes in genetic practice, we moved from a chromosome diagnostic and largely risk-giving type of counselling to a situation where direct information could frequently be given on a high risk pregnancy. There has also been a shift towards a more outgoing approach, more effort being directed towards informing the professions and the public of genetic services available by means of circulars, lectures, and the provision of library and information services.

In keeping with national policy these efforts have been concentrated on our own region. It is difficult to ascertain the degree to which we are meeting the needs of the region for genetic services, except in one field, namely prenatal diagnosis on age grounds alone. We know that very few patients are referred elsewhere for this indication (Maryon-Davis, 1978) and we know how many mothers resident in the region we are seeing. We had estimated that in 1971 to 1976 no more than $2 \%$ of mothers giving birth in the 35 to 39 age group, and $12 \%$ of the older mothers, had been referred for prenatal diagnosis (Polani et al., 1976). We now have accurate data for the whole of 1976 and it has been estimated that these proportions were $3 \%$ for the 35 to 39 group and $23 \%$ for the 40 and over group; preliminary figures for 1977 show that about $48 \%$ of the latter group had been referred (Alberman et al., 1979). The low figure for the younger age group reflects our policy of not accepting patients aged less than 38 unless there is some indication other than age. There are little similar data from elsewhere, but Milunsky (1975) estimated that in 1974 only $4.1 \%$ of pregnant women in Massachusetts over 35 years of age had an amniocentesis done for prenatal diagnosis. Mikkelsen (1976) reported that in 1974 this was true in $14.7 \%$ of women having children when they were 40 or more in Denmark, though this proportion had apparently doubled in 1975, and Bartsch (1978) found that, in $1976,25 \%$ of mothers of 35 or more in Göteberg, Sweden, had undergone amniocentesis.

\section{AMNIOCENTESIS UPTAKE}

We can use the present data on prenatal diagnosis to make some other points. About 1 in 5 pregnant women seeking advice on prenatal diagnosis did not undergo the test. About a quarter of these had aborted spontaneously before the test was carried out. In the remainder, the test was not carried out mostly because it was not indicated for the risk specified, or because the counselling odds suggested a relatively tolerable risk.

\section{SUCCESS RATE}

In $7 \%$ of those undergoing amniocentesis for any of the indications, no result was obtained. This figure was lower in those who needed only a single tap. Galjaard (1976) (also in Niermeijer et al., 1976) quotes lower failure rates based on an inquiry covering 46 centres in 8 countries in Western Europe and a much lower proportion of repeat taps $(4.3 \%$ against our $12 \%$ ). We too find that dry taps or bloodstained fluid are the commonest causes of failure, followed, in order of importance, by failure to establish satisfactory cell cultures. However, some of these failures were related to a suspected sick or dying fetus. We also suspect that culture failure may not be independent of cellular abnormality and therefore does not occur at random. This clearly is important in dictating the course of action when cultures fail in otherwise satisfactory samples of fluid.

\section{RESULTS}

The overall fetal abnormality rate agrees with the proportions detected in the 6000 amniocenteses reviewed by Galjaard (1976), with the annotation in the Lancet (1977), and with the 10000 amniocenteses reviewed by Golbus (1978).

As already reported a number of times (FergusonSmith, 1976; Niermeijer et al., 1976; Polani et al., 1976; Simpson et al., 1976; Sachs et al., 1977; Lancet, 1978; Mikkelsen et al., 1978; Proceedings of III European Prenatal Diagnosis Conference, 1978), 
the proportions of trisomic fetuses (including trisomy 21) related to maternal age is higher than that suggested by data on surviving infants, especially with Down's syndrome. This has been variously attributed to inaccurate data on survivors, selective mortality of affected fetuses during later pregnancy and in the neonatal period, and biased sampling or biased reporting. Clearly, clusters of these factors are likely to operate, possibly in different combinations and proportions in different populations.

We find a similar frequency to that described in published reports of trisomic fetuses in pregnant women who had previously had a trisomic fetus (J. Hamerton, 1976, personal communication; Galjaard, 1976; Golbus, 1978). For pregnancies where a parent was a translocation carrier, our findings are difficult to compare with published data, in which generally centric fusions involving chromosome 21 are not distinguished from interchanges of other types (Lancet, 1977; Proceedings of III European Prenatal Diagnosis Conference, 1978).

The results of AFP studies for high risk of NTD yielded almost $4 \%$ abnormal fetuses. This agrees well with the expectation of risk of recurrence of neural tube defects, at least those compatible with fetal survival to the end of the fourth month of pregnancy, in an area of relatively low population prevalence like south-east England. However, in this account we are reporting our total workload and its results. Because of our involvement with amniotic fluid AFP investigation from its inception, we have often received, and include, split samples from collaborating centres developing the technique. This may have resulted in an overrepresentation of cases of raised AFP either because of fetal abnormality or for other reasons.

Nearly $20 \%$ of fetuses studied for biochemical abnormalities turned out to be abnormal. This agrees with expectation for the disorders under investigation, which behave as recessives. Golbus (1978), in his review, assembled 565 pregnancies that had been investigated for biochemical errors; $132(23.4 \%)$ of them were shown to be abnormal. Galjaard (1978) has summarised data on amniotic studies for inborn errors in North America and Europe. Of 251 investigations in European laboratories in which the biochemical status of the fetus was precisely determined in respect of the object of the test, $54(22 \%)$ amniotic cell studies turned out to give an abnormal test result.

The importance of validating the results obtained when a pregnancy terminates needs to be stressed again. Apart from one example of missed trisomy 18 because of culture failure, we committed four errors of sexing in almost 2000 pregnancies, fortunately when the problem of sex was not relevant to the pre-

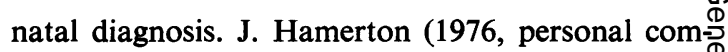
munication) collected information on 3315 preg ${ }^{+}$ nancies from 7 studies including the 2 North American ones. Ten errors (3 per 1000) were reported, in 8 instances errors of sex recognition $(2 \cdot 4$ per 1000$)$ and in 2 failure to recognise trisomy 21. Two of the sexing errors were, like two of ours $\vec{\pi}$ misrecognition of a female fetus, an error which? clearly must be attributed to a labelling or similain mistake.

In conclusion we find that the proportion of amniocenteses which gave informative results, thew proportion of abnormalities according to the indie cation for the test, and the outcomes of pregnancy are similar to those described in reports from other centres. Where outcome was known, $90 \%$ of the pregnancies screened ended in live born babies, $4 \%$ were terminated for fetal abnormality, less than $1 \%$ for non-medical reasons, and the remaining $6 \%$ ended as a fetal loss or neonatal death.

As can be expected from a subject that is still new and not fully explored, details are changing anc emphasis is shifting. Clearly, for example, the findings of the UK Collaborative Study (1977) on serum AFP will alter the approach to the prenatal diagnosis of NTD. Equally, the changing pattern of parental age at reproduction in most Westerns societies will shift the age criteria for the selection of pregnancies at high risk for chromosome disorders (Philip et al., 1977; Holmes, 1978), while the develop@ ment of better understanding of some inborn errors $\overrightarrow{0}$ and of fetal blood sampling, will enlarge the scope oB direct counselling for genetic biochemical anomalies? The major problem in this field that will still remaiñ. relates to those abnormalities of structure in which no correlated biochemical or cytological tests exis at present.

We are glad to acknowledge the help of our colleaguesิ in the PRU past and present: Professor J. L? Hamerton, who was Senior Lecturer in Cytogenetics until 1969, and L. Button, S. Embury, C. Fear A. Fenton, F. Giannelli, L. Kelberman, M. N. Rㅡ. King, S. Kohlinsky, I. Martin, D. E. Mutton, M. EN Pembrey, N. Polani, M. Fraser Roberts, P. Robson? and A. I. Taylor. We also thank Mr T. Coltart ands his colleagues of the Guy's Obstetrics Departmentw and the many other obstetricians and paediatrician who have helped us over the years. This work haso been supported by the DHSS, the SETRHA, and the Spastics Society.

\section{References}

Adinolfi, A., Adinolfi, M., and Lessof, M. H. (1975). Alpha feto-protein during development and in disease. Journal of Medical Genetics, 12, 138-151. 
Alberman, E., Berry, A. C., and Polani, P. E. (1979). Planning an amniocentesis service for Down syndrome. Lancet, 1,50 .

Bartsch, F. K. (1978). Indications, technique and limitations of amniocentesis. In Towards the Prevention of Fetal Malformation, pp. 138-151. Ed. by J. B. Scrimgeour. Edinburgh University Press, Edinburgh.

Blunt, S., Berry, A. C., Seller, M. J., and Vaughan Williams, C. A. (1977). Prenatal diagnosis of $4 \mathrm{p}-$ syndrome. Journal of Medical Genetics, 14, 232-233.

Brock, D. J. H., and Sutcliffe, R. G. (1972). Alpha-fetoprotein in the antenatal diagnosis of anencephaly and spina bifida. Lancet, 2, 197-199.

Campbell, S., Grundy, M., and Singer, J. D. (1976). Early antenatal diagnosis of spina bifida in a twin fetus by ultrasonic examination and alpha-fetoprotein estimation. British Medical Journal, 2, 676.

Fensom, A. H., Benson, P. F., Babarik, A. W., Grant, A. R., and Jacobs, L. (1977). Fibroblast phosphodiesterase deficiency in Niemann-Pick disease. Biochemical and Biophysical Research Communications, 74, 877-883.

Fensom, A. H., Benson, P. F., and Baker, J. E. (1978) A rapid method for assay of branched-chain keto acid decarboxylation in cultured cells and its application to prenatal diagnosis of maple syrup urine disease. Clinica Chimica Acta, 87, 169-174.

Fensom, A. H., Benson, P. F., and Blunt, S. (1974). Prenatal diagnosis of galactosaemia. British Medical Journal, 4, 386-387.

Fensom, A. H., Benson, P. F., Blunt, S., Brown, S. P., and Coltart, T. M. (1976). Amniotic cell 4-methylumbelliferyl$\alpha$-glucosidase activity for prenatal diagnosis of Pompe's disease. Journal of Medical Genetics, 13, 148-149.

Ferguson-Smith, M. A. (1976). Prospective data on Down syndrome in relation to maternal age. Lancet, 2, 252.

Galjaard, H. (1976). European experience with prenatal diagnosis of congenital disease: a survey of 6121 cases. Cytogenetics and Cell Genetics, 16, 453-467.

Galjaard, H. (1978). Early diagnosis and prevention of genetic disease: molecules and the obstetrician. In Towards the Prevention of Fetal Malformation, pp. 3-18. Ed. by J. B. Scrimgeour. Edinburgh University Press, Edinburgh.

Golbus, M. S. (1978). Prenatal diagnosis of genetic defectswhere it is and where it is going. In Birth Defects, pp. 330 337. Ed. by J. W. Littlefield, J. de Grouchy, and F. J. G. Ebling. Excerpta Medica, Amsterdam.

Holmes, L. B. (1978). Genetic counseling for the older pregnant woman: new data and questions. New England Journal of Medicine, 298, 1419-1421.

Kohn, G., and Robinson, A. (1970). Tetraploidy in cells cultured from amniotic fluid. Lancet, 2, 778-779.

Lancet (1977). Who's for amniocentesis? Lancet, 1, 986-987.

Lancet (1978). Maternal age and Down's syndrome. Lancet, 2, 24-25.

Maryon-Davis, A. R. (1978). Who's for Amniocentesis? An Investigation of Factors Affecting the Selection and Referral of High Risk Mothers for Prenatal Diagnosis in the SouthEast Thames Region, 1975-1976. M.Sc. Thesis, University of London.

Medical Research Council (1978). Working party on amniocentesis report. An assessment of the hazards of amniocentesis. British Journal of Obstetrics and Gynaecology, 85, Suppl. 2, 1-41.
Mikkelsen, M. (1976). Prenatal chromosomal diagnosis. In Prenatal Diagnosis. INSERM Colloquium, June 1976, Vol. 61, pp. 95-103. Ed. by A. Boúe. INSERM, Paris.

Mikkelsen, M., Nielsen, G., and Rasmussen, E. (1978). Cost-effectiveness of antenatal screening for chromosome abnormalities. In Towards the Prevention of Fetal Malformation, pp. 209-216. Ed. by J. B. Scrimgeour. Edinburgh University Press. Edinburgh.

Milunsky, A. (1975). Risk of amniocentesis for prenatal diagnosis. New England Journal of Medicine, 293, 932-933.

National Institute of Child Health and Human Development. National Registry for Amniocentesis Study Group (1976). Midtrimester amniocentesis for prenatal diagnosis: safety and accuracy. Journal of the American Medical Association, 236, 1471-1476.

Niermeijer, M. F., Sachs, E. S., Jahodova, M., TichelaarKlepper, C., Kleijer, W. J., and Galjaard, H. (1976). Prenatal diagnosis of genetic disorders. Journal of Medical Genetics, 13, 182-194.

Philip, J., Bang, J., and Madsen, M. (1977). Should the indications for prenatal chromosome analysis be changed? British Medical Journal, 2, 1117-1119.

Polani, P. E., Alberman, E., Berry, A. C., Blunt, S., and Singer, J. D. (1976). Chromosome abnormalities and maternal age. Lancet, 2, 516-517.

Polani, P. E., and Polani, N. (1969). Chromosome anomalies, mosaicism and dermatoglyphic asymmetry. Annals of Human Genetics, 32, 391-402.

Proceedings of the III European Prenatal Diagnosis Conference, Munich, April 1978. (In the press.)

Ramsay, C. A., Coltart, T. M., Blunt, S., Pawsey, S. A., and Giannelli, F. (1974). Prenatal diagnosis of xeroderma pigmentosum. Report of the first successful case. Lancet, 2 , 1109-1112.

Sachs, E. S., Jahoda, M. G. J., Niermeijer, M. F., and Galjaard, H. (1977). An unexpected high frequency of trisomic fetuses in 229 pregnancies monitored for advanced maternal age. Human Genetics, 36, 43-46.

Seller, M. J. (1975). Prenatal diagnosis of a neural tube defect: Meckel syndrome. Journal of Medical Genetics, 12, 109-110.

Seller, M. J. (1977). Dark-brown amniotic fluid. Lancet, 2, 983-984.

Simpson, N. E., Dallaire, L., Miller, J. R., Siminovich, L., Hamerton, J. L., Miller, J., and McKeen, C. (1976). Prenatal diagnosis of genetic disease in Canada. Report of a collaborative study. Canadian Medical Association Journal, 115, 739-746.

Stirling, J. L., Robinson, D., Fensom, A. H., Benson, P. F., and Baker, J. E. (1978). Fluorimetric assay for prenatal detection of Hurler and Scheie homozygotes or heterozygotes. Lancet, 1, 147.

UK Collaborative Study on Alpha-fetoprotein in Relation to Neural Tube Defects (1977). Maternal serum alphafetoprotein measurement in antenatal screening for anencephaly and spina bifida in early pregnancy. Lancet, $\mathbf{1}$, 1323-1332.

Requests for reprints to Professor P. E. Polani, Paediatric Research Unit, Prince Philip Research Laboratories, Guy's Hospital Medical School, London SE1 9RT. 